\title{
Pengaruh pemberian tepung biji durian sebagai subtitusi jagung dalam pa- kan ayam petelur terhadap rasio heterofil-limfosit dan produksi telur
}

\section{The effect of feeding durian seed flour as corn subtitution on heterophyl- lymphocyteratio and egg production}

\author{
K. Nissa *, F. Wahyono dan N. Suthama \\ Fakultas Peternakan dan Pertanian Universitas Diponegoro, Semarang
}

Submitted: 20 September 2018, Accepted: 16 Juli 2019

\begin{abstract}
ABSTRAK: Penelitian ini bertujuan untuk mengetahui pengaruh pemberian tepung biji durian sebagai pengganti jagung terhadapserum glutamate oksaloasetat transminase (SGOT), rasio heterofil/limfosit (H/L), dan hen day production (HDP). Materi yang digunakan adalah 120 ekor ayam petelur fase layer dengan 4 macam perlakuan dan 5 ulangan. Perlakuan meliputi $\mathrm{T} 0=$ tanpa tepung biji durian (kontrol); $\mathrm{T} 1=3 \%$ tepung biji durian pengganti jagung; $\mathrm{T} 2=6 \%$ tepung biji durian penggantijagung; dan T3= $9 \%$ tepung biji durian pengganti jagung. Parameter yang diamati adalah SGOT, rasio H/L, dan HDP. Data dianalisis ragam dan dilanjutkan uji wilayah ganda Duncan apabila perlakuan menunjukkan pengaruh nyata. Hasil penelitian menunjukkan, pemberian tepung biji durian pada taraf 9\% (T3) berpengaruh nyata $(\mathrm{P}<0,05)$ terhadap SGOT, rasio H/L,dan HDP. Kesimpulan penelitian bahwa pemberian tepung biji durian sampai taraf $9 \%$ meningkatkan SGOT, rasio H/L, dan menurunkan HDP.
\end{abstract}

Kata kunci: tepung biji durian; SGOT; rasio heterofil-limfosit; produksi telur; ayam petelur.

ABSTRACT: The aim of this study was to determine the effect of feeding durian seed flour as corn substitution on heterophyl/lymphocyte (H/L) ratio and hen day production (HDP). Experimental animals were 120 birds of laying hens allocated into for 4 treatments with 5 repications. Treatments applied were $\mathrm{T} 0=$ without durian seed flour (control); $\mathrm{T} 1=3 \%$ durian seed flour to substitute corn; $\mathrm{T} 2=$ 6\% durian seed flour to substitute corn; and T3: $9 \%$ of durian seed flour to substitute corn. The parameters observed were serum glutamate oksaloasetate transaminase (SGOT), H / L ratio and hen day production (HDP). Data were analyzed using analysis of varian sand continued to Duncan's multiple range test if the treatments showed the significant effect. The results showed that the treatment with durian seed flour at the level of 9\% (T3) was significant ( $<<0.05)$ on SGOT, H/L ratio, and HDP. In conclusion, durian seed flour at the level of $9 \%$ resultsincreases SGOT, H / L ratio,and a decreases HDP.

Keywords: durian seed flour; SGOT; heterophyl-lymphocyte ratio; egg production; laying hen.

*Corresponding Author: nisaanifa88@gmail.com

DOI: 10.21776/ub.jiip.2019.029.02.01 


\section{PENDAHULUAN}

Pengembangan ayam petelur di Indonesia semakin meningkat seiring dengan meningkatnya permintaan telur untuk memenuhi kebutuhan protein hewani masyarakat. Meningkatnya produksi ayam petelur berimbas pada kenaikan harga pakan yang sebagian besar masih impor salah satunya adalah jagung. Oleh karena itu perlu adanya subtitusi jagung dengan bahan pakan lain yang memiliki kandungan nutrisi hampir sama dengan jagung. Pemilihan biji durian sebagai subtitusi jagung dalam pakan dikarenakan kandungan energi yang hampir sama. Kandungan energi metabolis pada biji durian sebesar $2225 \mathrm{Kkal} / \mathrm{kg}$ (Guntoro, 2015) sedangkan pada jagung sebesar $3394 \mathrm{Kkal} / \mathrm{kg}$ (Rasyaf, 1990). Biji durian mentah mengandung zat antinutrisi berupa asam siklopropena dan asam oksalat yang bersifat racun dan berefek pada pengikatan protein, oleh karena itu perlu pengolahan lebih lanjut unuk mengurangi antinutrisi tersebut. Salah satu pengolahan biji durian adalah dengan melalui proses perebusan dan pengeringan kemudian menjadikannya sebagai tepung.

Ayam petelur mempunyai umur produksi yang panjang sehingga membutuhkan ketahanan tubuh yang memadai agar tidak mengganggu produksi telur, sehingga penggunaan biji durian yang diolah secara direbus sebagai subtitusi jagung perlu diamati pengaruh antinutrisi terhadap kondisi dan ketahanan tubuh. Konsumsi antinutrisi yang berlebih dapat menyebabkan cekaman pada ayam petelur sehingga dapat menurunkan produksi telur. Penelitian bertujuan untuk evaluasi limbah biji durian sebagai bahan subtitusi jagung pada ayam petelurdan mengetahui pengaruh pemberian tepung biji durian sebagai subtitusi jagung dilihat dari perubahan serum glutamate oksaloasetat transminase (SGOT), rasio heterofil/ limfosit dan produksi telur.

\section{MATERI DAN METODE Pembuatan Tepung Biji Durian}

Prosedur penelitian diawali dengan pembuatan tepung biji durian. Biji durian yang telah didapatkan kemudian direbus selama 1 jam kemudian diiris tipis dan dijemur hingga kering. Biji durian kering kemudian dihaluskan menggunakan mesin grinder dan didapatkan tepung biji durian. Tepung biji durian kemudian dianalisis proksimat untuk mengetahui kandungan nutriennya.

\section{Ternak dan Pakan Penelitian}

Penelitian menggunakan 120 ekor ayam petelur umur 40 minggu dan diberi pakan sebanyak 120 g/ekor/hari. Bahan penyusun pakan terdiri dari jagung kuning, bungkil kedelai, bekatul, tepung ikan, tepung cangkang kerang, kalsium karbonat (CaCO3), premix, dan tepung biji durian. Formulasi dan kandungan nutrien pakan dapat dilihat pada Tabel 1. Perlakuan penelitian yaitu level penambahan tepung biji durian sebagai pengganti jagung. Perlakuan penelitian adalah sebagai berikut: T0 $=$ Pakan basal tanpa tepung biji durian $\mathrm{T} 1=$ Pakan $+3 \%$ tepung biji durian $\mathrm{T} 2=$ Pakan $+6 \%$ tepung biji durian $\mathrm{T} 3=$ Pakan $+9 \%$ tepung biji durian 
Tabel 1. Formulasi dan Kandungan Nutrien Pakan Penelitian

\begin{tabular}{|c|c|c|c|c|}
\hline Bahan Pakan & T0 & $\mathrm{T} 1$ & $\mathrm{~T} 2$ & T3 \\
\hline & & $----\%$ & 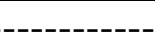 & ----- \\
\hline Jagung & 43,00 & 40,00 & 37,00 & 34,00 \\
\hline Tepung biji durian & 0,00 & 3,00 & 6,00 & 9,00 \\
\hline Bekatul & 18,00 & 18,00 & 18,00 & 18,00 \\
\hline Bungkil kedelai & 19,50 & 19,50 & 19,50 & 19,50 \\
\hline Tepung ikan & 10,00 & 10,00 & 10,00 & 10,00 \\
\hline $\mathrm{CaCO} 3$ & 3,50 & 3,50 & 3,50 & 3,50 \\
\hline Tepung cangkang kerrang & 5,00 & 5,00 & 5,00 & 5,00 \\
\hline Premix & 1,00 & 1,00 & 1,00 & 1,00 \\
\hline Minyak & 0,50 & 0,50 & 0,50 & 0,50 \\
\hline TOTAL & 100,50 & 100,50 & 100,50 & 100,50 \\
\hline \multicolumn{5}{|l|}{ Kandungan nutrisi $\operatorname{pakan}^{1}(\%)$} \\
\hline Energi metabolis $(\mathrm{kkal} / \mathrm{kg})^{2}$ & 2858,72 & 2861,69 & 2869,65 & 2879,60 \\
\hline Protein kasar ${ }^{1}$ & 17,69 & 17,70 & 17,71 & 17,72 \\
\hline Serat kasar ${ }^{1}$ & 4,42 & 4,93 & 5,43 & 5,94 \\
\hline Lemak kasar $^{1}$ & 6,29 & 6,17 & 6,06 & 5,95 \\
\hline Kalsium $^{1}$ & 3,29 & 3,28 & 3,27 & 3,26 \\
\hline Pospor $^{1}$ & 0,68 & 0,67 & 0,66 & 0,65 \\
\hline Asam Oksalat ${ }^{3}$ & 0 & 0,0114 & 0,0228 & 0,0342 \\
\hline Asam lemak siklopropena ${ }^{4}$ & 0 & 0,0189 & 0,0378 & 0,0567 \\
\hline
\end{tabular}

Sumber: ${ }^{1}$ Hasil analisis proksimat pakan di Laboratorium Ilmu Nutrisi dan Pakan, Fakultas Peternakan dan Pertanian, Universitas Diponegoro, Semarang

${ }^{2}$ Perhitungan berdasarkan rumus Balton

${ }^{3}$ Hasil Analisis Laboratorium Penelitian dan Pengujian Terpadu, Universitas Gadjah Mada,Yogyakarta ${ }^{4}$ Hasil Analisis Laboratorium Kimia Organik, FMIPA, Universitas Gadjah Mada, Yogyakarta.

\section{Parameter Penelitian}

Ayam dipelihara selama 4 minggu dengan pakan sesuai perlakuan, kemudian darah diambil melalui vena brachialis yang berada di bawah sayap menggunakan spuit berukuran $3 \mathrm{ml}$. Darah kemudian dimasukkan ke dalam vacuum tube $\mathrm{K} 3$ yang sudah diberi label perlakuan untuk dianalisis serum glutamate oksaloasetat transaminase (SGOT) dan vacuum tubeyang berisi antikoagulan EDTA untuk dianalisis heterofil dan limfosit. Analisis SGOT menggunakan spektrofotometri dan analisis heterofil dan limfosit menggunakan preparat apus darah yang sudah kering kemudian diamati melalui mikroskop dan dihitung presentase heterofil dan limfosit. Persentase heterofil dan limfosit kemudian dikalikan dengan jumlah leukosit sehingga didapatkan jumlah heterofil dan limfosit.
Jumlah leukosit dihitung melalui bilik hitung improve neubauer setelah darah diencerkan dengan larutan Turk (Yuniwarti dan Muliani, 2014). Produksi telur dihitung setiap hari dan hen day production dihitung dengan rumus:

$$
\text { HDP : } \frac{\text { Jumlah Telur Perhari }}{\text { Jumlah Ayam }} \times 100 \%
$$

\section{Rancangan Percobaan dan Analisis Data}

Penelitian disusun menggunakan rancangan acak lengkap (RAL) dengan 4 perlakuan dan 5 ulangan. Data dianalisis dengan menggunakan sidik ragam untuk mengetahui pengaruh perlakuan. Apabila perlakuan berpengaruh nyata dilanjutkan dengan uji wilayah ganda Duncan pada taraf $5 \%$. 


\section{HASIL DAN PEMBAHASAN}

Kadar SGOT akibat pemberian biji durian $(\mathrm{T} 1, \mathrm{~T} 2$, dan $\mathrm{T} 3)$ lebih tinggi $(\mathrm{P}<0,05)$ dibanding kontrol (T0) (Tabel 2.) Kandungan antinutrisi pada biji durianberupa asam siklopropena dan asam oksalat diasumsikan dapat meningkatkan kadar SGOT karena adanya gangguan kerja sel sel hati dan mengakibatkan fungsi hati tiak normal. Namun SGOT tidak hanya spesifik dipengaruhi oleh kerusakan hati sehingga tidak dapat digunakan sepenuhnya untuk memprediksi gangguan hati karena enzim SGOT juga ditemukan di organ lain dalam konsentrasi rendah seperti ginjal dan otot rangka (Nasution, Adi dan Santosa, 2015). Menurut Cahyono dan Suharjo (2009), semakin tinggi nilai enzim SGOT maka se- makin meningkat pula gangguan pada sel. Meskipun antinutrisi biji durian didominasi oleh asam siklopropena, namun peningkatan kadar SGOT lebih banyak dipengaruhi oleh asam oksalat. Asam oksalat dapat diserap oleh usus dan sebagian asam oksalat yang tidak dapat diabsorbsi, di dalam darah berikatan dengan kalsium dan dikeluarkan bersama urin. Oksalat yang berikatan dengan kalsium membentuk kalsium oksalat yang menyebabkan gangguan ginjal (Dewi, Dwiloka dan Setiatini, 2007). Hal ini dapat dilihat pada Tabel 2. yang menunjukkan adanya peningkatan yang signifikan pada parameter SGOT dan rasio $\mathrm{H} / \mathrm{L}$.

Tabel 2. Serum glutamate oksaloasetat transaminase (SGOT), rasio heterofil/limfosit (H/L) dan hen day production (HDP) pada ayam petelur yang diberi tepung biji durian

\begin{tabular}{lrrrr}
\hline & \multicolumn{5}{c}{ Perlakuan } \\
\cline { 2 - 5 } Parameter & \multicolumn{1}{c}{ T0 } & \multicolumn{1}{c}{ T1 } & \multicolumn{1}{c}{ T2 } & \multicolumn{1}{c}{ T3 } \\
\hline SGOT & $223,49^{\mathrm{b}}$ & $240,11^{\mathrm{a}}$ & $242,13^{\mathrm{a}}$ & $242,54^{\mathrm{a}}$ \\
Rasio H/L & $0,64^{\mathrm{b}}$ & $0,74^{\mathrm{a}}$ & $0,77^{\mathrm{a}}$ & $0,73^{\mathrm{a}}$ \\
HDP & $64,28^{\mathrm{a}}$ & $61,19^{\mathrm{a}}$ & $60,36^{\mathrm{a}}$ & $46,67^{\mathrm{b}}$ \\
\hline
\end{tabular}

a,b) Superskrip berbeda pada baris yang sama menunjukkan perbedaan yang nyata $(\mathrm{P}<0,05)$

Pemberian tepung biji durian dengan level pemberian sampai $9 \%$ (T1 sampai T3) juga nyata meningkatkan nilai rasio $\mathrm{H} / \mathrm{L}$ pada ayam petelur (0,730,77).dibandingkan dengan perlakuan tanpa tepung biji durian $(\mathrm{T} 0=0,64)$ (Tabel 2). Nilai rasio H/L pada perlakuan kontrol dan pemberian biji durian berkisar antara 0,64 sampai 0,77 termasuk diatas nilai normal.Sesuai dengan penelitian Emadi dan Kermanshahi (2007) menyatakan bahwa tingkatketahanan tubuh pada unggas berdasarkan nilai rasio $\mathrm{H} / \mathrm{L}$ dapat dibedakan menjadi tiga kriteria yaitu rendah $(0,2)$, normal $(0,5)$, dan tinggi $(0,8)$. Semakin tinggi nilai rasio $\mathrm{H} / \mathrm{L}$, maka semakin tinggi tingkat cekaman yang dialami ayam (Kusnadi, 2009). Tingginya rasio $\mathrm{H} / \mathrm{L}$ pada pemberian tepung biji durian sampai taraf $9 \%$ dapat diasumsikan bahwa ayam petelur mengalami cekaman. Peningkatan rasio $\mathrm{H} / \mathrm{L}$ berkaitan dengan kandungan antinutrisi pada biji durian yang berupa asam siklopropena dan asam oksalat. Antinutrisi direspon oleh ayam sebagai antigen eksogenus yang bersifat mengganggu penggunaan dan metabolisme nutrisi pada ayam.Gangguan metabolisme nutrisi menyebabkan penggunaan tidak maksimal, akibatnya tubuh menjadi kekurangan nutrisi tertentu yang berkaitan dengan cekaman. Antinutrisi asam siklopropena bersifat penenang sehingga mengubah metabolisme lemak (Widodo, 2012) apabila komposisi lemak berubah, lebih banyak lemak stearat daripada oleat, akhirnya asam lemak stearat sulit terdegradasi dan diserap oleh usus sehingga ter- 
jadi penimbunan lemak yang tinggi. Asam oksalat pada biji durian juga diketahui dapat mengganggu penyerapan mineral kalsium dan zat besi (Dewi, Dwiloka, dan Setiani.,2017), dan menghambat penyerapan zinc (Widhyari, 2012). Akibatnya menyebabkan penurunan ketahananan tubuh dalam hal ini dapat dilihat dari kenaikan rasio $\mathrm{H} / \mathrm{L}$.

Penurunan produksi telur (hen day production) dapat dikaitkan dengan kenaikan serum glutamate oksaloasetat transminase (SGOT) dan rasio $\mathrm{H} / \mathrm{L}$ (Tabel 2). Pemberian tepung biji durian pada taraf $9 \%$ (T3) menunjukkan nilai HDP paling rendah $(\mathrm{P}<0,05)$ dibanding perlakuan yang lain. Asam siklopropena yang diketahui dapat menghambat pemecahan lemak sehinggadiasumsikan terjadi penimbunan lemak dalam ovarium danmenyebabkan penurunan produksi telur. Menurut Hertamawati dan Hariadi (2008), tingginya deposit lemak dalam tubuh dapat menyebabkan masak kelamin dini, padahal kondisi reproduksi belum siap mendukung produksi telur yang optimum. Demikan pula Qi et al. (2016) menyatakan bahwa asam siklopropena dapat menghambat sintesis protein kuning telur. Apabila sintesis protein, terutama pada kuning telur, terhambat maka pembentukan telur secara keseluruhan terganggu dan menyebabkan produksi telur menjadi rendah.

\section{KESIMPULAN}

Berdasarkan hasil penelitian dapat disimpulkan bahwa pemberian tepung biji durian sebagai substitusi jagung dalam pakan ayam petelur sampai taraf $9 \%$ meningkatkan serum glutamt oksaloasetat transaminase dan rasio heterofil/limfosit serta menurunkan hen day production (HDP).

\section{DAFTAR PUSTAKA}

Cahyono, J.B. dan B. Suharjo. 2009. Hepatitis A. Edisi 1. Yogyakarta: Kanisius.
Dewi, S.K., B. Dwiloka, B. E. Setiani. 2017. Pengurangan kadar oksalat pada umbi talas dengan penambahan arang aktif pada metode pengukusan. J. Aplikasi Teknologi Pakan, 6(2), 1-4.

Emadi, M and H. Kermanshahi. 2007. Effect of turmeric rhizome powder on the activity of some blood enzymes in broiler chickens. Intl. J. Poult. Sci., 6(1), 48-51.

Guntoro, E. J. 2015. Evaluasi kualitas nutrisi limbah buah durian ampas tahu fermentasi dengan Phanero chaete chrysosporium dan Neuro spora cras$s a$. Fakultas Peternakan. Universitas Andalas.

Hertamawati, R. T dan M. Hariadi. 2008. Pembatasan pakan menunda masak kelamin, menurunkan biometri organ reproduksi dan deposisi lemak pada puyuh (Coturnix coturnix japonica). Media Kedokteran Hewan, 24(1), 5558.

Kusnadi, E. 2009. Perubahan malonaldehida hati, bobot relative bursa fabricius dan rasio heterefil/limfosit ayam broiler yang diberi cekaman panas. Med. Pet., 32(2), 81-87

Nasution, A.Y., P. Adi, dan P.A. Santosa. 2015. Pengaruh ekstrak propolis terhadap kadar SGOT (serum glutamic oxaloacetic transaminase) dan SGPT (serum glutamic pyruvic transaminase) pada tikus putih (Rattus norvegicus) galur wistar dengan diet tinggi lemak. Majalah Kesehatan FKUB, 2(3), 120 126.

Qi, M., L-h. Sun, J. Guo, J. Liu, Y-z. Duan, X. Wang, C-p. Zeng, D-s. Qi, and N-y. Zhang. 2017. Abnormal characteristics of eggs laid by hens fed with high levels of cottonseed meal. J. Appl. Poult. Res., 26, 122-129. 
Rasyaf, M. 1990. Bahan Pakan Unggas Indonesia. Yogyakarta: Kanisius.

Widhyari, S. D. 2012. Peran dan dampak defisiensi zinc $(\mathrm{Zn})$ terhadap sistem tanggap kebal. Wartazoa, 22(3), 141148.
Widodo, W. 2012. Bahan Pakan Unggas Non Konvensioal. UGM Press, Yogyakarta.

Yuniwarti, E. Y. W. dan H. Muliani. 2014. Status heterofil, limfosit dan rasio $\mathrm{H} / \mathrm{L}$ berbagai itik lokal di Provinsi Jawa Tengah. J. Ilmu Ternak. 1(5), 22-27. 